\title{
Transformation Model of Government Policy on Task Force Through Coronavirus Disease 2019 Pandemic Handling Strategy in the COVID Tourism Ambassador Program in South Sulawesi Province, Indonesia
}

\author{
Aslinda Aslinda ${ }^{1 *}$, Muhammad Akmal Ibrahim², Sukri Palutturi ${ }^{3}$ \\ ${ }^{1}$ Department of Public Administration, Universitas Negeri Makassar, Makassar, Indonesia; ${ }^{2}$ Department of Administrative \\ Science, Universitas Hasanuddin, Makassar, Indonesia; ${ }^{3}$ Department of Health Policy and Administration, Faculty of Public \\ Health, Universitas Hasanuddin, Makassar, Indonesia
}

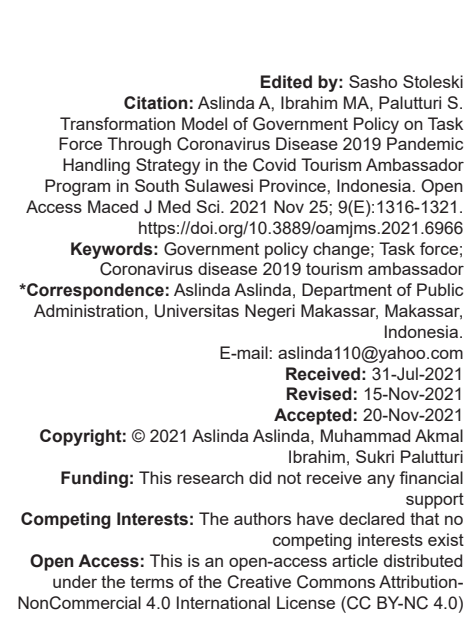

\section{Introduction}

Coronavirus disease 2019 (COVID-19) has become a global pandemic [1], [2]. Indonesia along with more than 200 other countries in the world have become victims of the ferocity of this disease [3]. The COVID-19 pandemic in South Sulawesi Province, in particular, has infected hundreds of thousands of people and is the cause of many deaths [4]. Based on the official data issued by South Sulawesi government (2020-2021), the total population of the South Sulawesi Province is $9,426,885$ people, while those who were infected with COVID were 53,569 people. In other words, around 553 out of 100,000 were infected with COVID. In the case of COVID-19 deaths, latest data recorded 819 deaths or 8.4 out of 1,000 (data dated February 19, 2021) due to the disease. This COVID-19 data raised its specific problems, especially in economic and social aspects. Therefore, the government of South Sulawesi takes various strategies to suppress the spread of COVID-19, including policy transformations and establishment of strategic programs to tackle COVID-19.

Policy transformations occur due to public dissatisfaction with the impact of public policies, especially during the implementation stage. This causes the policy continuously being formed throughout the implementation, starting from presidential decrees, ministerial decisions, followed by decisions from the implementing agencies related to policy outputs and target groups' compliance to the decisions made by those agencies. These decisions affect both on the actual conditions, either undesirable or desirable, which lead to the policy changes in the implementation of government programs [5]. 
Policy transformations are defined as major or minor changes in a policy subsystem. Major changes refer to changes in the core aspects of a government policy, while minor changes refer to changes in important aspects of policy namely the government policy. Policy transformation is an important element of public policy activity (Cheng, 2019; True, Jones, and Baumgartner, 2019). The concept of strategy in Advocacy Coalition Framework (ACF) theory states that every advocacy coalition adopts one or more strategies to change the behaviors of various government authorities to realize its goals. The most common advocacy strategies are legal instrument changes (Aslinda, 2016; Sabatier, 1988).

The policies of the COVID-19 control and handling task force in the Province of South Sulawesi have undergone several changes. Changes in government policy regulations aim to make appropriate, focused, fast, integrated, and synergistic measures among regional apparatuses in the COVID-19 Task Force within the scope of the South Sulawesi provincial government. Based on these policy changes, the government designed a COVID-19 handling strategy by involving multistakeholders in the implementation of the COVID-19 handling program in South Sulawesi, called the Synergy and Collaborative program.

The stakeholders involved in controlling or handling COVID-19 in South Sulawesi are the Government of South Sulawesi Province - in this case the Governor, the Provincial Health Office, Civil Society Organization; Private parties; Medical personnels; Religious leaders; Public figures; Indonesian Army/ Police (TNI/Polri); and Academics. There have been many strategies carried out by the government, but based on the field observations that have been previously conducted, the author still found many problems regarding the policies issued by the government to handle COVID-19. These policies are still not efficient and optimal in reducing the confirmed positive number of COVID-19 cases in South Sulawesi. This can be seen from the high number of COVID-19 cases which were spread among several districts in South Sulawesi.

The increase of COVID-19 case rate indicates the absence of synergy and continuality between actors in carrying out as well as supervising COVID-19 policies. Besides, the public lacks awareness to implement rules set by the government. For example, there are still many people who do outdoor activities without wearing a mask, are not disciplined in washing their hands, and do not realize the importance of social distancing. In addition, the public also lack awareness to check themselves at the hospital after experiencing the initial symptoms of COVID-19, or patients who are clearly COVID-19-positive but unable to remember whom they interacted within the past 14 days. The government is facing this tracing problem due to logistical factors and the large population of South Sulawesi.

Based on the problems stated above, the authors assumed that the ACF theory introduced by Sabatier (1988) [6] is appropriate to be applied to investigate the phenomenon of changes in policy regulations and strategies used by the government to handle the COVID-19 pandemic. Normatively, COVID-19 pandemic handling policy has changed from the predefined blueprint. This results in an empirical phenomenon, as previously stated, which is very suitable to research policy changes using the perspective of ACF [7]. This research is different from the previous research which focused only on urban and forestry issues. There has been no research on policy changes related to the handling of COVID-19 pandemic in South Sulawesi.

This study aimed to identify and analyze changes in task force policies as well as strategies used in handling the COVID-19 pandemic through the Tourism Ambassador program in South Sulawesi which is considered as an effective model for handling COVID-19.

\section{Methods}

This research was conducted by applying qualitative method that emphasizes interpretation and phenomena holistically. The analysis used was the model of government policy transformation in the task force through the COVID-19 pandemic handling strategy in the COVID tourism ambassador program in South Sulawesi. The reason for choosing strategies and transformations in COVID-19 handling policy is because the strategies and policy changes implemented are the government's effort to suppress the spread of COVID-19 in South Sulawesi. Furthermore, this research was conducted in Makassar City, specifically the South Sulawesi Provincial Health Office.

This study was participated by informants (participants) who were involved in the COVID Ambassador Tourism Program in South Sulawesi. Data source for this study come from; (1) archives and documents on program/activity, (2) interview with selected informants, and (3) field observation. It is important to utilize various data sources because it allows the application of triangulation strategy. Triangulation is a means to improve the validity of study findings Miles and Huberman [8].

\section{Results and Discussion}

Based on the data and information obtained from field, the results of research on the changes in the policy to handle COVID in South Sulawesi through a strategy carried out by the government based on 
the theoretical perspective of ACF can be described starting with policy changes, COVID handling strategies, and impact/output of government policy programs.

\section{Government policy change in COVID-19 handling in South Sulawesi}

Based on the analysis results of field data, this study found that there were changes in the policies carried out by the government related to COVID-19 handling strategy in South Sulawesi. At the national level, there was also a government mandate to make policy changes, namely the Presidential Decree No. 07 of 2020 concerning the Task Force for the Acceleration of Handling COVID-19. The government policy that underwent changes is Presidential Decree No. 9 of 2020 concerning Amendments to the Decree of the President of the Republic of Indonesia No. 07 of 2020 concerning the Task Force for the Acceleration of 2019 and the strategy for handling Corona-19.

Changes in government policies on COVID-19 handling strategy at the national level, as described above, are not included in the subject of this study. This research only focused on changes in policy for COVID-19 in South Sulawesi, with the aim of increasing the effectivity of COVID-19 control and handling, which are still developing until now. The changes in policy as referred above are described in the following Table 1.

Based on Table 1, the Provincial Government of South Sulawesi has made policy changes, especially regarding the COVID-19 handling acceleration task force. This policy changes occurred because of the first structure, which is the head of COVID-19 handling, the Chairman of BPBD (Mr. Nimal Lahamang) and the Head of the Health Office as deputy chairman, did not go as expected (Governor's Statement, April 7, 2020). Therefore, in accordance with the direction of the Ministry of Internal Affairs, the structure of the COVID-19 handling acceleration task force is chaired by the Governor of South Sulawesi Province.
In addition, the research found that there were various changes in the government regulatory policies related to the Regulation of the Minister of Health (Permenkes) of the Republic of Indonesia No. 09 of 2020 to Presidential Decree (Kepres) No. 11 of 2020 regarding regulations for large-scale social restrictions (PSBB) to accelerate the handling of COVID-19 in South Sulawesi. Through this policy, the Governor of South Sulawesi Province established a PSBB in all districts in South Sulawesi totaling 27 Regencies/Cities. Based on the author's observations, however, the policy has changed. From the predetermined 27 regencies, only one city and one regency that were determined to implement PSBB, which is Makassar City 2 times for 14 days each) and Gowa Regency once for 14 days. On the one hand, the uneven implementation of government policies on PSBB and, on the other hand, the confirmed positive number of COVID-19 cases in South Sulawesi Province still has an increasing trend, especially in several regencies.

Changes in government regulatory policy were carried out with the consideration of the economic conditions of the community which had worsened since the COVID-19 pandemic started in South Sulawesi. The people's income in the second quarter of 2020 was only around 5.32, far below the national standard compared to income in the fourth quarter of 2019 which was $6.48 \%$. Before the COVID-19 pandemic, economic growth in South Sulawesi had increased to $7 \%$.

Furthermore, one of the policy changes previously described Keputusan Gubernur Sulsel (2020) [9], the amendment of the Regulation of the Governor of South Sulawesi Province Number 930/III/2020 to the Regulation of Governor of South Sulawesi Province Number 954/III/2020 went through another change with the Regulation of Governor of South Sulawesi Province Number 2206/IX/2020 on the establishment of COVID-19 handling acceleration task force. These policy changes are a form of strategy in the centralized handling of COVID and synergy between the local and the provincial government through the COVID Tourism program where patients are quarantined and

Table 1: Changes in COVID-19 handling policies

\begin{tabular}{|c|c|c|c|c|}
\hline Policy & Substance of policy & Policy change & Substance of policy & Substance of policy change \\
\hline Presidential Decree & COVID-19 handling & Presidential Decree & Amendment to & 1. Changes to the membership \\
\hline Number 7 of 2020 & acceleration task force & Number 9 of 2020 & $\begin{array}{l}\text { Presidential Decree No. } \\
7 \text { of } 2020 \text { on COVID-19 } \\
\text { Handling Acceleration } \\
\text { Task Force }\end{array}$ & $\begin{array}{l}\text { composition of COVID-19 Handling } \\
\text { Acceleration Task Force } \\
\text { 2. Changes to the composition of } \\
\text { implementers } \\
\text { 3. Necessary funding for Task Force } \\
\text { activities }\end{array}$ \\
\hline $\begin{array}{l}\text { Regulation of the Governor } \\
\text { of South Sulawesi Province } \\
\text { Number } 930 / I I I \text { of } 2020\end{array}$ & $\begin{array}{l}\text { Formation of COVID-19 } \\
\text { handling acceleration } \\
\text { task force }\end{array}$ & $\begin{array}{l}\text { Regulation of Governor of } \\
\text { South Sulawesi Province } \\
\text { Number } 954 / \text { III of } 2020\end{array}$ & $\begin{array}{l}\text { Amendment to } \\
\text { Regulation of Governor } \\
\text { of South Sulawesi } \\
\text { Province Number } 930 / \\
\text { III/2020 on the formation } \\
\text { of COVID-19 handling } \\
\text { acceleration task force }\end{array}$ & $\begin{array}{l}\text { 1. Policy changes occur under the } \\
\text { direction of the Minister of Internal } \\
\text { Affairs, where the head of the local } \\
\text { government acts as the Chair of } \\
\text { the Task Force } \\
\text { 2. There are issues for both } \\
\text { outpatient department leaders } \\
\text { who were previously appointed as } \\
\text { Chairman and Deputy Chairman, } \\
\text { which in fact causes problems in } \\
\text { the implementation of the task } \\
\text { force }\end{array}$ \\
\hline
\end{tabular}


isolated in luxury hotels. The purpose of this policy change was to accelerate the control and handling of COVID-19 patients in South Sulawesi.

The changes in COVID-19 handling in South Sulawesi do not mean that issues are no longer present. There are still problems, such as (a) quarantine process is not yet centralized, (b) synergy is not complete between all elements involved in COVID-19 handling, (c) limited hospital room facilities, and (d) many people do not heed health protocols. In addition, problems also arise in the handling of COVID-19 patients at hospitals. Conflicts often occur between the family of COVID-19 patient and medical personnel due to the limited availability of hospital room facilities and services, causing people to be wary and hesitate of health examinations. Due to this condition, the Governor of South Sulawesi took a quick measure by establishing COVID-19 control clusters both in the regency/city and in the province level.

\section{Sulawesi}

\section{COVID-19 handling strategy in South}

The concept of strategy based on ACF theory states that every advocacy coalition adopts one or more strategies to change the behavior of various government authorities. To realize its policy objectives, the most common advocacy strategy is changes in legal instrument [10]. Based on this concept, the policy strategy undertaken by the government - in this case the Governor of South Sulawesi — related to the handling of COVID-19 through the COVID-19 Tourism Ambassador program are (a) Contact tracing and (b) Testing and education.

The COVID tourism program is a program of centralized treatment of asymptomatic patients and patients with mild symptoms at a predetermined hotel. The COVID tourism ambassador program is a collaborative or synergy program between the Provincial Government of South Sulawesi. The synergy means that the government established clusters in both Regency/ City and Province level to handle COVID-19 adapting the strategy to identify people who have contracted COVID-19 in hope that this can (a) widely eliminate the chain of COVID-19 transmission by separating the sick and the healthy, (b) prevent mild symptoms from developing into severe symptoms due to better healthcare, and (c) form a "COVID Champion Ambassador" to take the role of educator in the community. The target of this program consists of: (a) People who have had close contact with positive COVID-19 patients, (b) people who display mild symptoms, (c) people who came back from travel outside South Sulawesi, and (d) asymptomatic positive patients or patients with mild symptoms. The following excerpt is the result of an interview conducted with HS, the Head of the Public Health Division, regarding the COVID Tourism Ambassador program:
The reason we call them "COVID Tourism Ambassadors" is because during their isolation period at the hotel, they are educated about the COVID-19 pandemic, with the hope that after they managed to complete it well, they can go home and help officers to educate people in their communities. In addition, this COVID Tourism Ambassador is considered to be an effective COVID-19 handling model, because frankly we really need more educators.

Interview with Mr. HT, December 2020

The result of the interview above supports the idea that the program carried out by the government can support COVID-19 handling strategy through the Contact Tracing program, which is a collaborative policy between the Provincial and Regency/City government to break the chain of COVID-19 transmission. For the testing and contact tracing program, the government has provided 700 trained surveillance personnels at the province level and 100 volunteers at the regency/ city level to conduct contact tracing on people infected with COVID-19. The mechanism in which this Contact Tracing is implemented is as follows. First, the local government assigns a task force to carry out contact tracing of infected patients. After the government at the regency/city level determines the people who are infected through contact tracing (proven by a swab letter), the local government then issues a recommendation to refer the infected to the province level COVID-19 handling cluster. Based on the recommendation from the district/city level, the provincial government of South Sulawesi provides a centralized quarantine facility at luxury hotels in Makassar City, after conducting a coordination process between the provincial government and hotel management. The following is a list of hotels included in the list of COVID-19 tourist attractions or centralized quarantine venues in South Sulawesi (Table 2).

Table 2: List of hotels included in COVID tourism program in South Sulawesi 2021

\begin{tabular}{ll}
\hline Hotel name & Patient count (Person) \\
\hline Swiss Bell Hotel & 170 \\
Grand Imawa Hotel & 91 \\
Lynt Hotel & 90 \\
Grand Celino Hotel & 118 \\
Remcy & 60 \\
Kamanre Palopo Hotel & 23 \\
Almadera Hotel & 103 \\
Kenari Hotel & 62 \\
Citra Medika Hotel & 30 \\
Yasmin Hotel & 63 \\
Marina Bantaeng Hotel & 36 \\
\hline
\end{tabular}

Activities offered to COVID-19 patients while in quarantine at the hotel as part of the COVID Tourism Ambassador program are: (a) Daily sport activities; (b) COVID-19 education; (c) COVID-19 Ambassador training/preparation; (d) supervision to ensure optimal nutrition intake; (e) psychological support; (f) laboratory examination; and $(\mathrm{g})$ health monitoring.

The following is an interview with Mr. HT, the Head of the South Sulawesi Cluster regarding the contact tracing policy strategy: 
The collaboration or synergy between the local and provincial government on the handling of COVID-19 through the COVID tourism program in hotels results in the increasing number of people who were infected with COVID-19 and recovered. This is because people are no longer traumatized by COVID-19, especially during independent isolation or quarantine at the hotel. The high rate of patient recovery is because people feel comfortable with the good atmosphere and service provided by the hotel.

Interview with Mr. HT, January 20, 2021

The author also conducted interview with informants about the result or output of the COVID-19 Tourism Ambassador program through contact tracing program:

The COVID tourism ambassador program, through the contact tracing program, is carried out by the task force at the regency and provincial level. The result of this program has contributed to a decreased number of cases by $25 \%$ out of the total COVID patients in South Sulawesi.

Interview with Ml, January 2021

Next, the result of interview with another informant about the barriers to conduct contact tracing in the COVID tourism program is:

The issue faced by this contact tracing program is that people in South Sulawesi still lack awareness to examine themselves at the hospital after experiencing initial symptoms of COVID. People or patients who are clearly positive for COVID are unable to remember well whom they met in the past 14 days. The government is facing this tracing issue due to logistical factors and the large population number in South Sulawesi.

Interview with ID, December 2020

Another strategy carried out by the government in this COVID-19 Tourism Ambassador program is the education program, involving synergy between the Provincial level and Regency/City level governments as well as various organizational elements such as 1000 religious' figures, 6000 community leaders/public figures, COVID alumni, and 1 volunteer, military, and police officers. This educational program policy is regulated in the Regulation of Governor Number 02 of 2021 on the discipline and enforcement of health protocol laws. The process of education strategy in COVID-19 tourism is expected to change people's behavior so they consistently comply with COVID prevention protocol — often known as "3M;" mask, maintain distance, avoid crowd (menghindari kerumunan) and wash hand using soap (mencuci tangan pakai sabun). The purpose of the education program is to (a) increase the percentage of people who change their behavior from deviant to obedient, (b) reduce the number of COVID-19 cases in the task force's cluster/ area, and $(\mathrm{C})$ change the risk-zoning status in the task force's cluster/area. The following is interview excerpts with community leaders about COVID-19 education.
The COVID education policy mandated by the Provincial government involves various elements, even people who have been exposed to COVID-19 to help educate the public about COVID-19 prevention. This policy is very good because it helps the public understand the importance of behavior shift to protect themselves from COVID-19 by wearing mask, keeping a distance, and avoiding crowds as well as washing hand using soap.

Interview, 20 January 2021

Next is the result of interview with $A R$, the Deputy Chair of the Task Force about the result or output from the COVID Tourism program through the educational policy program:

The education program is carried out by all elements of society at the district and provincial level. This program has contributed to a decrease in the number of COVID-19 cases by $25 \%$ out of the total COVID-19 number in South Sulawesi.

Interview with AR, January 2021

The following is the result of interview with informant from the public health sector about obstacles in the COVID Tourism educational program:

The obstacle found in the COVID tourism program stems from the large number of COVID-19 cases, around $70 \%$ are independently isolated at home. If all of them go to quarantine at the hotel, we can ensure that there will be no transmission from them. Independent isolation at home increases the chance of transmitting COVID-19 to family members who live under the same roof. The obstacle is that many people still lack the understanding of the importance of hotel isolation.

Interview with AK, December 2020

The description of government strategy in the COVID ambassador tourism policy through the contact tracing and education program reveals that the government's policy aims to break the chain of COVID-19 transmission in South Sulawesi by creating synergy between all elements of the government both at the Regency/City and Provincial level in South Sulawesi. Although the government has created a strategy through the COVID Tourism Ambassador program, this program has not been able to significantly reduce the number of COVID-19 cases, as shown by the fact that $70 \%$ of COVID-19 patients still choose independent isolation at their house, so the transmission of COVID-19 in household cluster is still relatively high. In addition, the contact tracing program is still non-optimal because of a few reasons, among others; (a) some public attitude that consider COVID-19 as a frightening disease, (b) low awareness of the public to get examined at the hospital after experiencing the initial symptoms of COVID-19, (c) people who have tested positive for COVID-19 through swab test are unable to provide information to the government regarding who they met in the last 14 days, (d) supervision from the 
government is not continuous, and $(d)$ the education program carried out by the government seems rushed and is not carried out continuously.

Policies in the public sector are made by the government, public officials, as well as the citizens they represent [11]. These actors decide whether to carry out policies related to public matters. The choice of doing or not doing something regarding certain public matters is referred to by analysts as nonpolicies. According to Kraft and Furlong (2004) [12], nonpolicies are instances where the government ignores or chooses not to address a public issue, allowing the private sector or market forces to handle it. Other research shows that in a pandemic crisis or not, the government as a policy maker should make policies that can answer the challenges and problems of the times, meet the needs of the community, and improve the welfare of society as a whole. Not the other way around, the government actually makes controversial public policies that can trigger unrest and create chaos in society [13].

The research finds by Subadra [14], namely, the regional regulation on cultural tourism was amended during the COVID-19 outbreak to strengthen the use of local cultures for tourism adapting both national and international tourism policies to lead to a more responsible tourism designating Bali's local indigenous cultures of Tri Hita Karana and Sad Kerthi as basis of cultural tourism development in Bali; and more importantly, Bali's government issued particular policies and executed immediate measures to reopen tourism in Bali which totally shut down due to the pandemic. The Indonesian government has set a policy package to accelerate the performance of the tourism sector as well as to attract tourist visits in the midst of the corona virus outbreak and several countries have designed and implemented policies to save the sustainability of tourism development [15].

\section{Conclusion}

Based on the results of analysis of the data and information as explained in the previous section, it can be concluded that (1) changes in policy related to the acceleration of COVID-19 control and handling in South Sulawesi resulted in a policy output that showed a decrease in the number of COVID-19 positive cases and (2) implementing the strategy through the COVID-19 Tourism Ambassador program as a model for handling COVID-19 in South Sulawesi is the right strategy.

\section{References}

1. Kozloff N, Mulsant BH, Stergiopoulos V, Voineskos AN The COVID-19 global pandemic: Implications for people with schizophrenia and related disorders. Schizophr Bull. 2020;46(4):752-7. https://doi.org/10.1093/schbul/sbaa051 PMid:32343342

2. Peng M. Outbreak of COVID-19: An emerging global pandemic threat. Biomed Pharmacother. 2020;129:110499.

3. Chakraborty I, Maity P. COVID-19 outbreak: Migration, effects on society, global environment and prevention. Sci Total Environ. 2020;728:138882. https://doi.org/10.1016/j. scitotenv.2020.138882

PMid: 32335410

4. Palutturi S, Aminuddin S, Arifin MA, Asnawi A. COVID-19: Indonesia Butuh Kita. Yogyakarta: Pustaka Pelajar; 2020.

5. Aslinda I. The Strategy and Political Resources in the changing of spatial policy. Bus Bureau J Admin Organ Sci 2016;22(1):60-7.

6. Sabatier PA. An advocacy coalition framework of policy change and the role of policy-oriented learning therein. Policy Sci. 1988;21(2):129-68

7. Bandelow NC, Vogeler CS, Hornung J, Kuhlmann J, Heidrich S. Learning as a necessary but not sufficient condition for major health policy change: A qualitative comparative analysis combining ACF and MSF. J Comp Policy Anal. 2019;21(2):167-82.

8. Miles MB, Huberman AM. Qualitative Data Analysis: An Expanded Sourcebook. New York, United States: SAGE; 1994. p. 358.

9. Gubernur SulSel. Keputusan Gubernur Sulawesi-Selatan Nomor: 954/III/Tahun 2020 Perubahan Keputusan Gubernur Provinsi Sulawesi Selatan No. 930/llI/2020 Tentang Pembentukan Gugus Tugas Percepatan Penanganan Corona Virus Disease 19 (COVID-19); 2020.

10. Weible CM, Sabatier PA, McQueen K. Themes and variations: Taking stock of the advocacy coalition framework. Policy Stud J. 2009;37(1):121-40

11. Adhikari UR. The relationship of public policy to governance: Issues and strategies of Nepal. IJSRP. 2020;10(6):972-81.

12. Kraft ME, Furlong SR. Public Policy: Politics, Analysis, and Alternatives. Los Angeles: CQ Press; 2012. p. 592

13. Tuwu D, Laksmono BS, Huraerah A, Harjudin L. The dynamics of policies for handling the COVID-19 pandemic in the perspective of social welfare. Sosio Konsepsia. 2021;10(2):97-110.

14. Subadra IN. Cultural tourism and the Covid-19 pandemic: understanding government policies and balinese reactions. J Kajian Bali (J Bali Stud). 2021;11(1):1-22.

15. Sugihamretha ID. Policy response: Mitigating the impact of the COVID-19 outbreak in the tourism sector. Indones J Dev Plan. 2020;4(2):191-2016. 